\title{
Copper uptake potential of Philippine giant bamboo (Dendrocalamus asper) under varied initial copper concentration, water hardness and $\mathrm{pH}$
}

\author{
Jerwin Lawrence C. Go ${ }^{1}$, Cynthia F. Madrazo ${ }^{1}$, Aileen H. Orbecido ${ }^{1}$, Ma. Ellenita G. de Castro ${ }^{2}$ and Lawrence P. Belo ${ }^{1, *}$ \\ ${ }^{1}$ Department of Chemical Engineering, Gokongwei College of Engineering, De La Salle University, 2401 Taft Avenue, Manila 1004, \\ Philippines \\ ${ }^{2}$ Department of Biology, College of Science, De La Salle University, 2401 Taft Avenue, Manila 1004, Philippines
}

\begin{abstract}
Copper is a commonly used metal in construction, engineering, agriculture and water treatment. Consequently, increased copper concentrations resulting in adverse environmental effects is inevitable. Phytoremediation using Dendrocalamus asper or Philippine giant bamboo (PGB) is a viable option for treatment of copper-contaminated media, but their copper uptake potential remains largely unexplored. As such, the copper uptake of PGB was evaluated under varying environmental conditions, namely initial copper concentration, water hardness and $\mathrm{pH}$.Six-month old propagules were planted in artificially contaminated water in order to determine the copper uptake after 16 days of treatment. Using a BoxBehnken design of experiment, it was found that both initial copper concentration and $\mathrm{pH}$ have significant and proportional effects on copper uptake. However, due to possible speciation and/or competition, the optimum copper uptake occurred at $20 \mathrm{ppm} \mathrm{Cu}$ and $\mathrm{pH} 5$ (as opposed to 7). A mathematical equation, bearing an $\mathrm{R}^{2}=0.7097$, was constructed as a possible model for copper uptake of PGB to understand when PGB phytoremediation is most effective. At copper concentrations lower than $3.81 \mathrm{ppm}$, higher $\mathrm{pH}$ is beneficial to copper uptake and vice versa. Overall, phytoremediation using D. asper or PGB is effective especially at low $\mathrm{pH}$ and elevated copper concentrations.
\end{abstract}

\section{Introduction}

The Philippines is home to 421 rivers. Due to various anthropogenic activities, 50 of these can no longer sustain aquatic life. One known cause for river death is elevated levels of heavy metals, specifically copper [1]. High copper concentrations in rivers and surrounding soil have been known to cause widespread death of aquatic organisms, and until these concentrations are returned to their natural state, it is not possible for aquatic life to survive in these bodies of water [2].

Many technologies such as dredging, filtration, adsorption, electrocoagulation and phytoremediation are available and continually being developed for the removal of copper from contaminated water [3-6].

Phytoremediation involves growing specific plants in an area to remove pollutants whether by absorption, stabilization or some other mechanism [7]. It is ecofriendly, passive, non-invasive, inexpensive, and not labor intensive. However, it is relatively slow and is often limited by the maximum pollutant concentration the local flora can survive in [8]. In theory, it should be applied to light or moderately polluted areas that do not require immediate results wherein acceptable levels are achieved within ten years [7]. In reality, however, this criterion does not take into account the environmental state of the contaminated site. Pre-existing conditions such as the copper concentration, water hardness and $\mathrm{pH}$ of the river may have an effect on the copper uptake of phytoremediators, and hereby lies a gap in scientific knowledge.

In order to provide a clearer understanding of when phytoremediation will be effective, it will be assumed that the initial copper concentration, water hardness and $\mathrm{pH}$ affect the copper uptake of Philippine giant bamboo. This study will then verify this hypothesis.

\section{Materials and methods}

\subsection{Philippine giant bamboo}

Some plant species have been proven to sequester high concentrations of heavy metals in stems and leaves, but they often lack the biomass to make the amount of absorbed pollutant significant [9]. Philippine giant bamboo (Dendrocalamus asper) were used because of their sufficient biomass and fast growth rate of around 3 to $10 \mathrm{~cm}$ per day [10]. Six (6) month old propagules were sourced from the Department of Environmental and Natural Resources - Ecosystems Research and Development Bureau (DENR - ERDB).

\footnotetext{
Corresponding author: lawrence.belo@dlsu.edu.ph
} 


\subsection{Hydroponic solutions}

After sufficient washing, the bamboo plants were planted in 3-liter hydroponic solutions made from AR grade $\mathrm{CuSO}_{4}-5 \mathrm{H}_{2} \mathrm{O}, \quad \mathrm{MgSO}_{4}-7 \mathrm{H}_{2} \mathrm{O}, \quad \mathrm{CaCl}_{2}-2 \mathrm{H}_{2} \mathrm{O}$, simple Nutrient Addition Program (SNAP) solution, and distilled water. SNAP was jointly developed by the Bureau of Agricultural Research and the University of the Philippines Los Baños as a complete nutrient solution for hydroponic plant growth even without circulation of liquid. It contains calcium, nitrogen, potassium, phosphorus, magnesium, sulfur, iron, manganese, boron, zinc, copper, chlorine and molybdenum [11]. The hydroponic solutions also contained at most $3 \mathrm{~mL}$ of $2.4 \mathrm{M} \mathrm{NaOH}$ in order to increase the $\mathrm{pH}$. Note that the hydrates of magnesium sulfate and calcium chloride were added in an equimolar manner in order to vary the water hardness, but the values are presented as $\mathrm{CaCO}_{3}$.

\subsection{Statistical design}

Using Box-Behnken design, the hydroponic solutions contained varying initial copper concentration, water hardness and $\mathrm{pH}$. Consequently, for each factor, a minimum, a maximum and a midpoint are necessary. The initial copper concentrations used were based off the highest reading in the Meycauayan-Marilao-Obando river system, a dead river with elevated copper concentrations (3.14 ppm [12]), that of the acid mine drainage found in the Britannia Beach Mine wherein copper leachate resulted in the death of multiple rivers (20 ppm [13]) and the midpoint (11.57 ppm). Those of water hardness were taken as 0 (nutrient solution only), 90 (moderate water hardness) and $180 \mathrm{ppm}$ as $\mathrm{CaCO}_{3}$ (limit between hard and very hard water) [14]. The $\mathrm{pH}$ levels were then chosen because metal uptake is maximized between $\mathrm{pH} 5$ and 7 [15].

Copper uptake was used to quantify phytoremediation as this takes into account the change in liquid concentration and liquid volume, along with the mass of the plant. Simply put, it is the loss in mass of copper per unit plant. Mathematically, this is defined by Eq. 1 below.

$$
C U=\frac{C_{o} V_{o}-C V}{m}
$$

where $C U$ is copper uptake at time, $C_{o}$ is the initial concentration of copper in the liquid, $V_{o}$ is the initial volume of the liquid, $C$ is the final concentration of copper in the liquid, $V$ is the final volume of the liquid, and $m$ is the dried mass of the plant

After 16 days, aliquots were taken from the hydroponic solutions. These were then filtered to remove particles, before being vaporized in an Atomic Absorption Spectrophotometer (Shimadzu AA-6300). A calibration curve was then constructed using $0.05,1,5$, $10 \& 20 \mathrm{ppm} \mathrm{Cu}$ solutions made from copper sulfate pentahydrate with the proportional amount of SNAP solution. The spectrophotometer then yielded the final copper concentrations of the liquids. The plants were then dried at $65^{\circ} \mathrm{C}$ for 3 days and then weighed on an analytical balance.

\section{Results and discussion}

\subsection{Analysis of copper uptake}

It was observed that all of the hydroponic solutions showed a decrease in copper concentration. The hydroponic solutions initially at $3.14 \mathrm{ppm}$ copper decreased to $1.66-2.75 \mathrm{ppm}$. Those that were initially at $11.57 \mathrm{ppm}$ decreased to $3.08-7.34 \mathrm{ppm}$, while those that were initially at $20 \mathrm{ppm}$ decreased to $5.03-19.15 \mathrm{ppm}$.

After accounting for the change in volume and the mass of each individual plant (the average is 108.55 士 37.42 g), copper uptake was calculated using Eq. 1 (see Table 1).

Table 1. Copper uptake of $D$. asper at varied initial copper concentration, water hardness and $\mathrm{pH}$

\begin{tabular}{cccccc}
\hline Plant \# & Run \# & $\begin{array}{c}\text { Initial } \\
\text { Copper } \\
\text { Concen } \\
\text { tration } \\
\text { (ppm) }\end{array}$ & $\begin{array}{c}\text { Water } \\
\text { Hardness } \\
\text { (ppm } \\
\text { CaCO3) }\end{array}$ & pH & $\begin{array}{c}\text { Copper } \\
\text { Uptake } \\
\text { (mg Cu/g } \\
\text { dried } \\
\text { biomass) }\end{array}$ \\
\hline 1 & 13 & 3.14 & 0 & 6 & 0.0356 \\
2 & 9 & 20 & 0 & 6 & 0.3410 \\
3 & 5 & 3.14 & 180 & 6 & 0.0423 \\
4 & 3 & 20 & 180 & 6 & 0.2765 \\
5 & 18 & 3.14 & 90 & 5 & 0.0267 \\
6 & 17 & 20 & 90 & 5 & 0.7596 \\
7 & 1 & 3.14 & 90 & 7 & 0.0334 \\
8 & 10 & 20 & 90 & 7 & 0.3197 \\
9 & 4 & 11.57 & 0 & 5 & 0.5504 \\
10 & 14 & 11.57 & 180 & 5 & 0.1889 \\
11 & 11 & 11.57 & 0 & 7 & 0.1653 \\
12 & 15 & 11.57 & 180 & 7 & 0.1799 \\
13 & 7 & 11.57 & 90 & 6 & 0.2051 \\
14 & 6 & 11.57 & 90 & 6 & 0.3082 \\
15 & 8 & 11.57 & 90 & 6 & 0.2437 \\
16 & 12 & 11.57 & 90 & 6 & 0.1949 \\
17 & 16 & 11.57 & 90 & 6 & 0.2409 \\
18 & 2 & 11.57 & 90 & 6 & 0.2049 \\
\hline
\end{tabular}

These were then inputted into DesignExpert version 10 and forced into a quadratic equation containing three types of terms: (1) the independent terms: initial copper concentration (represented by A), water hardness (B) \& $\mathrm{pH}(\mathrm{C}),(2)$ their interaction terms: $\mathrm{AB}, \mathrm{AC} \& \mathrm{BC}$, and (3) the square of each independent term: $\mathrm{A}^{2}, \mathrm{~B}^{2} \& \mathrm{C}^{2}$. After eliminating insignificant terms (p-value greater than 0.05), it was determined that water hardness is insignificant, while initial copper concentration, $\mathrm{pH}$ and their interaction, are significant to the copper uptake of Philippine Giant Bamboo (see Table 2). 
Table 2. ANOVA table for the significant factors

\begin{tabular}{cccccc}
\hline Source & $\begin{array}{c}\text { Sum of } \\
\text { Squares }\end{array}$ & df & $\begin{array}{c}\text { Mean } \\
\text { Square }\end{array}$ & $\begin{array}{c}\text { F } \\
\text { value }\end{array}$ & $\begin{array}{c}\text { p-value } \\
\text { Prob }>\text { F }\end{array}$ \\
\hline $\begin{array}{c}\text { Model } \\
A\end{array}$ & 0.44 & 3 & 0.15 & 14.86 & 0.0001 \\
$\begin{array}{c}\text { Initial } \\
{[\mathrm{Cu}]}\end{array}$ & 0.30 & 1 & 0.30 & 31.05 & $<0.0001$ \\
$\boldsymbol{C}$ & & & & & \\
$\mathrm{pH}$ & 0.082 & 1 & 0.082 & 8.36 & 0.0119 \\
$\begin{array}{c}A C \\
\text { Residual } \\
\text { Cor } \\
\text { Total }\end{array}$ & 0.049 & 1 & 0.049 & 5.01 & 0.042 \\
\hline & 0.57 & 14 & $9.805 \mathrm{E}-003$ & & \\
\hline
\end{tabular}

\subsection{Empirical relationship between copper uptake, initial copper concentration and $\mathrm{pH}$}

Excluding water hardness, the statistical significance of the experimental factors confirms the hypothesis that environmental conditions such as initial copper concentration and $\mathrm{pH}$ may have an effect on the phytoremediation capabilities of Philippine giant bamboo. In order to better understand how these factors alter copper uptake, significant terms were fitted to an appropriate linear equation with an adjusted $r^{2}$ value of 0.7097. Considering that plants are involved and that there is inherent randomness between plants in absorbing copper, this shows that there is a strong relationship between copper uptake and the independent variables.

More specifically, Eq. 2 shows that increased initial copper concentration and $\mathrm{pH}$ have inherently positive effects on copper uptake; however, when both are present in higher levels, copper uptake is hindered.

$$
C U=-0.33+0.1025 * C_{o}+0.0504 * p H-0.0132 * C_{o} * p H(2)
$$

\subsection{Effect of initial copper concentration on copper uptake}

Of the various abiotic factors, the initial copper concentration of the solution seems to have the greatest effect on the copper uptake of the plant, and is directly related to the copper uptake of $D$. asper. This is in line with the findings of Chen et al. [16] where Moso bamboo, Phyllostachys pubescens, were planted both in pot and hydroponics. At the highest tested concentration of $600 \mathrm{mg} / \mathrm{kg} \mathrm{Cu}$, copper absorption was maximized most of which was stored in root vacuoles. However, this was accompanied by adverse effects such as inhibited enzymatic activities and altered thylakoids to the extent that the treatment almost killed the plants.

One proposed model for this phenomenon is known as the intensity/capacity model. Capacity refers to the amount of copper present in the environment, while intensity refers that which is readily available for plant uptake. More specifically, this refers to copper that is dissolved in aqueous solution. The more copper in the liquid solution, the more likely it is for the bamboo to uptake copper [17]. However, it is possible that at higher $\mathrm{pH}$, although the same amount of copper is present (capacity), less copper is readily available as free ions in the liquid (intensity).

\subsection{Effect of pH on copper uptake}

It can be seen from Eq. 2 that at copper concentrations higher than $3.81 \mathrm{ppm}$, the copper uptake actually decreases with increasing $\mathrm{pH}$, while at concentrations below $3.81 \mathrm{ppm}$, it is actually beneficial to have a higher $\mathrm{pH}$. This breakeven point may explain why findings of various researchers are not in agreement with one another i.e. Willscher et al. [18] found that copper uptake is decreased at lower $\mathrm{pH}$ due to competition of hydrogen ions with those of heavy metals and increased dissociation of $\mathrm{H}_{2} \mathrm{CO}_{3}$ on the cell walls, while Ginocchio et al. [17] found that plants grown in slightly acidic soils (pH 5.4-6.7) absorbed more copper than those grown in neutral soils ( $\mathrm{pH} 7.0-7.6)$.

One such theory that attempts to explain this breakeven point is known as the Biotic Ligand Model (BLM). The BLM assumes that plant roots absorb nutrients through various receptors known as biotic ligands. These binding sites may be enzymes such as ATPase that utilizes an ATP pump to transport the copper through the cell membrane or proteins such as the COPT protein which binds with copper to allow entry to the cell. These are then transported from the cytosol to the copper-dependent enzymes and proteins by copper chaperones [19].

The more free copper $\left(\mathrm{Cu}^{2+}\right)$ is present in the system, the more likely it is for copper to bind with these biotic ligands. At higher copper concentrations, the effect of increasing $\mathrm{pH}$ on copper ions may cause a decrease in readily available ions and ion mobility possibly due to decreased solubility, increased attraction to organic complexes or both [20]. On the other hand, competition of $\mathrm{H}^{+}$and available mobile copper ions may be the reason why low $\mathrm{pH}$ becomes a hindrance to copper uptake at low copper concentrations [21].

Within the limits provided $\left(3.14<[\mathrm{Cu}]_{0}<20\right.$; $5<\mathrm{pH}<7$ ), an optimal copper uptake of $0.650 \mathrm{mg}$ copper/g biomass is predicted to occur when the solution is initially at $20 \mathrm{ppm} \mathrm{Cu}$ and $\mathrm{pH}$ 5. Three additional runs were then performed at said conditions for verification of the optimum. These resulted in copper uptakes of $0.3987,0.4395$ and $0.5488 \mathrm{mg} \mathrm{Cu} / \mathrm{g}$ plant. Along with the previously measured copper uptake of Run 17, the average copper uptake was determined to be $0.5366 \mathrm{mg}$ $\mathrm{Cu} / \mathrm{g}$ plant, which is within $82.55 \%$ of the predicted value of 0.650 .

\subsection{Effect of water hardness on copper uptake}

With water hardness, there are conflicting evidences on the significance of its effect. Some researchers found that calcium and magnesium ions may compete with copper ions for binding sites. Thus, their presence may inhibit copper uptake and ameliorate toxic effects [20]. This was evident in experiments performed on aquatic ferns, rice and grapevine [22-24]. The effect of water hardness on the copper uptake of Philippine giant 
bamboo, however, seems to be insignificant, similar to findings on microalgae and hornworts [25-26].

This may be because plants contain different copper-transporting biotic ligands. Some may bind only with cuprous ions, while others with cupric ions. Some ligands may be specific to copper, while others may be non-specific and allow competition [27]. It is possible that for $D$. asper, the biotic ligands for copper may bind with free copper ions and hydrogen protons, but not calcium and magnesium cations.

\subsection{Strengths and limitations of the mathematical model}

Another way of presenting Eq. 2 is through a contour plot (see Fig. 1). Factor levels that produce a lower copper uptake are depicted in blue (upper left), while those that produce the higher copper uptake values are depicted in red (lower right). A more detailed gradient is provided on the left of the contour plot. It is clearly seen that higher initial copper concentration and lower $\mathrm{pH}$ results in an increase in copper uptake.

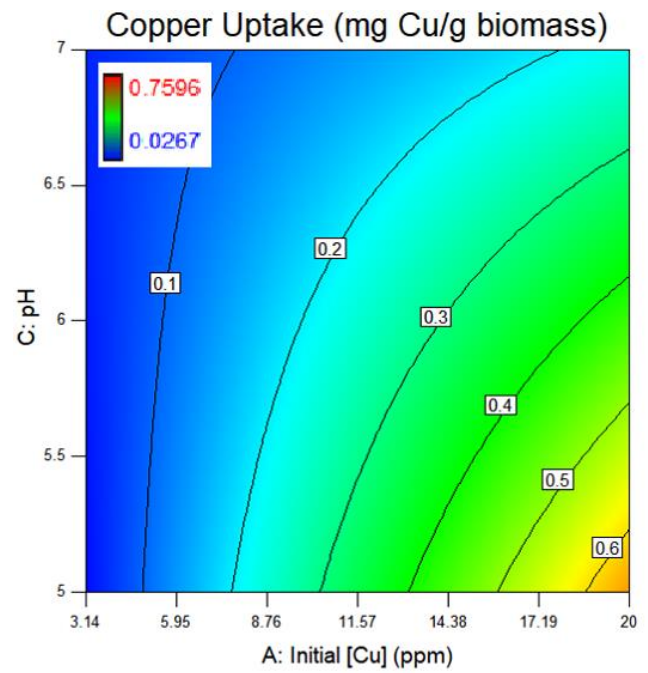

Figure 1. Contour plot of copper uptake with varying initial copper concentration and $\mathrm{pH}$

Using either Fig. 1 or Eq. 2, researchers may easily estimate the copper that will be absorbed by $D$. asper after 16 days of treatment. This may serve as a useful indicator for the effectiveness of phytoremediation given a certain level of copper contamination at a certain $\mathrm{pH}$.

Although the verifying runs managed to achieve $82 \%$ of the predicted optimum copper uptake, care must be taken when analyzing data beyond the experimental limits. Further studies are recommended in order to expand the limits of this model in terms of both factor levels and time period. The runs were ended after 16 days as the volume of liquid decreased by $25 \%$. In the future, studies under continuous flow pattern may help avoid this decrease in volume and allow for prolonged experimentation in order to analyze phytotoxic effects. Another limitation for this model is that it was performed in the presence of SNAP to allow for hydroponic testing. Trace metals found in SNAP may cause some differences between laboratory testing and field implementation. Although this effect was minimized by adding a constant amount of SNAP to each run, the presence of other heavy metals have been shown to either encourage or hinder metal uptake in plants. As such, another limitation is that the model assumes that other pollutants are not present in great amounts [28-29].

As this paper validates the significance of initial copper concentration and $\mathrm{pH}$ on the phytoremediation capabilities of $D$. asper, these factors should be taken into account when performing phytoremediation experiments. Plants that were previously excluded from the list of effective phytoremediators may actually uptake a lot of pollutants at an ideal $\mathrm{pH}$. Although optimum copper uptake for Philippine giant bamboo occurs at decreased $\mathrm{pH}$ and increased copper concentrations, this may not be true for other plants.

\section{Conclusion}

The Philippine giant bamboo, D. asper, is capable of removing high amounts of copper from artificially contaminated water (up to $0.650 \mathrm{mg} \mathrm{Cu} / \mathrm{g}$ dried plant at $20 \mathrm{ppm} \mathrm{Cu}$ and $\mathrm{pH} 5$ ), but its effectiveness is greatly affected by the initial copper concentration and $\mathrm{pH}$. Individually, each of these factors promotes copper uptake at increased levels, but together they may compete and hinder remediation. Phytoremediation using $D$. asper is most effective at high copper concentrations and low $\mathrm{pH}$. However, for lower copper concentrations (below 3.81), a neutral $\mathrm{pH}$ may be more ideal for $D$. asper. This phenomenon may have been caused by the presence of metal-specific biotic ligands, and it is recommended for future studies to explore this further.

Eq. 2 and Fig. 1 may be used to make more detailed estimates on copper uptake based on the environmental conditions present in order to ascertain the relative effectiveness of a remediation treatment.

The findings of this research project are made possible by the Department of Science and Technology - Engineering Research and Development for Technology (DOST-ERDT) through the financial support they have given. Vital also to this project is Mr. Jun Santos from the DENR-ERDB through whom the $D$. asper propagules were acquired. Credits also to Kimmie dela Cerna, Ivan Arcilla, Jessa Banua and Engr. Jennivee Chua for aiding the experimental procedures.

\section{References}

[1] Available online at www.greentumble.com/waterpollution-in-the-philippines-causes-and-solutions

[2] Available online at www.chinadaily.com.cn/china/ 2010-07/13/content_10096687.htm

[3] Moore, M., Locke, M. A., Jenkins, M., Steinriede, R. W., \& McChesney, D. S. Dredging effects on selected nutrient concentrations and ecoenzymatic activity in two drainage ditch sediments in the lower Mississippi River Valley. International Soil and Water Conservation Research 5(3), 2017 ,190-195. 
[4] Putra, R. S., Novarita, D., \& Cahyana, F. Remediation of lead $(\mathrm{Pb})$ and copper $(\mathrm{Cu})$ using water hyacinth [Eichornia crassipes (Mart.) Solms] with electro-assisted phytoremediation (EAPR). Proceedings 4th International Conference on Biological Science, 2015, pp. 020052(1-6).

[5] Vasudevan, S., Lakshmi, J., \& Sozhan, G. Electrocoagulation studies on the removal of copper from water using mild steel electrode, Water Environment Research 84(3), 2012, 209219.

[6] Sarkar, M., Rahman, A., \& Bhoumik, N. Remediation of chromium and copper on water hyacinth (E. crassipes) shoot powder, Water Resources and Industry 17, 2017, 1-6.

[7] Available online at https://www.nature.com/scitable/ knowledge/library/phytoremediation-17359669

[8] Cristaldi, A., Conti, G. O., Jho, E. H., Zuccarello, P., Grasso, A., Copat, C., \& Ferrante, M. Phytoremediation of contaminated soils by heavy metals and PAHs: A brief review, Environmental Technology \& Innovation 8, 2017, 309-326.

[9] Cluis, C. Junk-greedy greens: Phytoremediation as a new option for soil decontamination. BioTeach Journal 2, 2005, 61-67.

[10] Available online at www. furniturecebu.com/cebu/ 2012/03/26/giant-bamboo/

[11] Available online at www.snaphydroponics.com/ snap-hydroponics-solution

[12] Available online http://www.adb.org/results/water -pda-reducingmercury-and-heavy-metals contaminationmeycauayan-river

[13] Available at www.ushydrotech.com/files/6714/1409/ 9604/Impacts_of_Copper_on_Aquatic_Ecosyste ms_and_human_Health.pdf

[14] Available online at www.water.usgs.gov/edu/ hardness.html

[15] Available online at www.cropnutrition.com/efusoil-ph

[16] Chen, J., Shafi, M., Li, S., Wang, Y., Wu, J., Ye, Z., Liu, D. Copper induced oxidative stresses, antioxidant responses and phytoremediation potential of Moso bamboo (Phyllostachys pubescens), Scientific Reports 5, 2015, 13554.

[17] Ginocchio, R., Rodríguez, P. H., Badilla-Ohlbaum, R., Allen, H. E., \& Lagos, G. E. Effect of soil copper content and $\mathrm{pH}$ on copper uptake of selected vegetables grown under controlled conditions, Environmental Toxicology and Chemistry 21(8), 2002, 1736-1744.

[18] Willscher, S., Jablonski, L., Fona, Z., Rahmi, R., \& Wittig, J. Phytoremediation experiments with
Helianthus tuberosus under different $\mathrm{pH}$ and heavy metal soil concentrations, Hydrometallurgy 168, 2017, 153-158.

[19] Yruela, I. Copper in plants, Brazilian Journal of Plant Physiology 17(1), 2005, 145-156.

[20] Smith, K. S., Balistrieri, L. S., \& Todd, A. S. Using biotic ligand models to predict metal toxicity in mineralized systems, Applied Geochemistry 57, 2015, 55-72.

[21] Paquin, P. R., Gorsuch, J. W., Apte, S., Batley, G. E., Bowles, K. C., Campbell, P. G., ... Wu, K. B. The biotic ligand model: A historical overview, Comparative Biochemistry and Physiology Part C, 3(35), 2002, 3-35.

[22] Xu, Q., Qiu, H., Chu, W., Fu, Y., Cai, S., Min, H., \& Sha, S. Copper ultrastructural localization, subcellular distribution, and phytotoxicity in Hydrilla verticillata (L.f.) Royle, Environmental Science and Pollution Research 20(12), 2013, 8672-8679.

[23] Li, P., Wang, X., Zhang, T., Zhou, D., \& He, Y. Effects of several amendments on rice growth and uptake of copper and cadmium from a contaminated soil, Journal of Environmental Sciences 20(4), 2008, 449-455.

[24] Juang, K., Lee, Y., Lai, H., \& Chen, B. Influence of magnesium on copper phytotoxicity to and accumulation and translocation in grapevines. Ecotoxicology and Environmental Safety 104, 2014, 36-42.

[25] Markich, S., Batley, G., Stauber, J., Rogers, N., Apte, S., Hyne, R., Creighton, N. Hardness corrections for copper are inappropriate for protecting sensitive freshwater biota, Chemosphere, 60(1), 2005, 1-8.

[26] Markich, S. J., King, A. R., \& Wilson, S. P. Noneffect of water hardness on the accumulation and toxicity of copper in a freshwater macrophyte (Ceratophyllum demersum): How useful are hardness-modified copper guidelines for protecting freshwater biota? Chemosphere 65(10), 2006, 1791-1800.

[27] Ryan, B. M., Kirby, J. K., Degryse, F., Harris, H., McLaughlin, M. J., \& Scheiderich, K. Copper speciation and isotopic fractionation in plants: uptake and translocation mechanisms, New Phytologist 199(2), 2013, 367-378.

[28] Chigbo, C., Batty, L., \& Bartlett, R. Interactions of copper and pyrene on phytoremediation potential of Brassica juncea in copper-pyrene cocontaminated soil, Chemosphere 90(10), 2013, 2542-2548.

[29] García, G., Faz, Á., \& Cunha, M. Performance of Piptatherum miliaceum (Smilo grass) in edaphic $\mathrm{Pb}$ and $\mathrm{Zn}$ phytoremediation over a short growth period, International Biodeterioration \& 
Biodegradation 54(2-3), 2004, 245-250. 